\title{
Proceeding
}

7th INSHS International Christmas Sport Scientific Conference, 9-12 December 2012. International Network of Sport and Health

Science. Szombathely, Hungary

\section{Anthropometric characteristics of the young Czech population and their relationship to the national sports potential}

\author{
PAVEL GRASGRUBER , EDUARD HRAZDÍRA \\ Faculty of Sports Studies, Masaryk University, Brno, Czech Republic
}

\begin{abstract}
Grasgruber P, Hrazdira, E. Anthropometric characteristics of the young Czech population and their relationship to the national sports potential. J. Hum. Sport Exerc. Vol. 8, No. Proc2, pp. S120-S134, 2013. Anthropometric characteristics of young Czech men and women haven't been measured since 2001, due to the cancellation of the traditional anthropological survey in 2011. The project "Physical activity in the Czech republic" thus offered an opportunity to fill this gap and add some useful information about another physical features of the Czech population that usualy aren't addressed in anthropological studies. The investigated sample in the youngest age cohort (18-29 years) included 142 men and 137 women, and consisted of volunteers, who were measured during various public actions (primarily in Southern Moravia) during 20112012. Although the number of studied individuals was relatively small, their average height $(181.0 \pm 6.2 \mathrm{~cm}$ in men and $168.8 \pm 6.7$ in women) fits favourably the long-term trends of the secular height increase and confirms that Czech men and women belong to the very tallest in the world. Furthermore, the documented values of relative sitting height (52.63\% in men, $53.38 \%$ in women) and relative arm span (101.46\% in men, $99.23 \%$ in women) indicate that the Czech population can be viewed as short-limbed, when compared with other European nations. Considering that the average BMI of Czech national team members at Summer Olympics is consistently moderately above-average in comparison with other Europeans, it can be concluded that Czech men and women are physically well endowed mainly for strength sports of a more dynamic nature, where height is an important performance factor. These observations can have fundamental implications for the development and funding of talent programs, because they enable to target specific sports, whose requirements best correspond with the body type present in the Czech population. Key words: ANTHROPOMETRY, SECULAR TREND OF BODY HEIGHT, BODY PROPORTIONS, SPORTS TALENT SELECTION.
\end{abstract}

\section{Corresponding author. Resice 94. 67173. Czech Republic.}

E-mail: 32487@mail.muni.cz

7th INSHS International Christmas Sport Scientific Conference, 9-12 December 2012. International Network of Sport and Health Science. Szombathely, Hungary.

JOURNAL OF HUMAN SPORT \& EXERCISE ISSN 1988-5202

(c) Faculty of Education. University of Alicante

doi:10.4100/jhse.2012.8.Proc2.16 


\section{INTRODUCTION}

Nationwide anthropometric surveys have been a fixture in the Czech republic since 1951. They were conducted every 10 years and included representative samples of Czech children up to 18 years of age. Although the growth of 18-years old is not completely finished yet, the data could be used for the evaluation of the secular trend of body height (Table 1). Judging from the documented values, the average height of Czech boys in the age of 17-17,99 years has increased from $172.6 \mathrm{~cm}$ in 1951 to $180,3 \mathrm{~cm}$ in $2001(+7.3$ $\mathrm{cm})$. The height of Czech girls has increased from $161.9 \mathrm{~cm}$ in 1951 to $167.2 \mathrm{~cm}$ in $2001(+5.3 \mathrm{~cm})$. The difference between the height of boys and girls has thus widened from $10.7 \mathrm{~cm}$ to $13.1 \mathrm{~cm}$, and the ratio between their average height has increased as well, from 1.066 to 1.078 . At the same time, the young Czech population studied in 2001 could be regarded as one of the tallest in the world. The results of the 6th anthropological survey were independently replicated in the study of Jirkovský (2003), who reported average height $180.4 \pm 6.5 \mathrm{~cm}$ in a sample of 225 soldiers (age range 20.00-24.99 years) coming predominantly from northern and western parts of Bohemia.

Table 1. Continuing secular trend of body height in the Czech republic (age group 17-17.99 years). Data were computed from the growth curve (Vignerová et al., 2006).

\begin{tabular}{lcccccc} 
& $\begin{array}{c}1951 \\
\left({ }^{*} 1933\right)\end{array}$ & $\begin{array}{c}1961 \\
\left({ }^{*} 1943\right)\end{array}$ & $\begin{array}{c}1971 \\
\left({ }^{*} 1953\right)\end{array}$ & $\begin{array}{c}1981 \\
\left({ }^{*} 1963\right)\end{array}$ & $\begin{array}{c}1991 \\
\left({ }^{*} 1973\right)\end{array}$ & $\begin{array}{c}\mathbf{2 0 0 1} \\
\left({ }^{*} 1983\right)\end{array}$ \\
\hline Boys & 172.6 & 173.8 & 175.8 & 177.9 & 179.0 & 180.3 \\
Girls & 161.9 & 162.7 & 163.6 & 165.2 & 166.3 & 167.2 \\
Difference $(\mathrm{cm})$ & 10.7 & 11.1 & 12.2 & 12.7 & 12.7 & 13.1 \\
Ratio & 1.066 & 1.068 & 1.075 & 1.077 & 1.076 & 1.078 \\
\hline
\end{tabular}

Unfortunately, the 7th nationwide anthropological survey in 2011 was not realized due to the lack of funding from the Ministry of Health. Therefore, the EU-funded project "Physical activity in the Czech republic" (CZ 1. 07/2. 3. 00/20 0044) that started in summer 2011 offered an opportunity to fill this gap. Furthermore, it also enabled to measure some proportional characteristics that are often ignored in anthropometric surveys (e.g. sitting height, arm span). The knowledge of all these bodily parameters could be used for the development of rational sports talent programs targeting specific sports, whose requirements stand closest to the body type prevailing in the Czech population.

In addition, the determination of a typical "national somatotype" would be a crucial factor going beyond basic anthropometric characteristics. This task is much more difficult, however, because an individual somatic type is influenced by both genetic and environmental factors (the level of nutrition and physical activity). We can expect that only data coming from little industrialized world regions would have some information value, because they would represent physically active people with low body fat. Nevertheless, during the last two decades, multiple medicinal studies indirectly assessed differences in muscle development from the comparison of fatfat-free mass ratio at a given BMl (Deurenberg et al., 1998, 1999, 2002). This comparison already produced some very interesting results. For example, a meta analysis of ethnic comparisons (Deurenberg et al., 1998) points to a remarkably muscular physiques of Pacific Islanders, followed distantly by US blacks, "Caucasians" (mostly of US and West European descent), Chinese, Southeast Asians (Indonesians, Malays) and Ethiopians. However, the number of studied ethnicities is still insufficient and in Europe, it is limited to English and Dutch speaking populations. 
Nevertheless, an interesting approach to this problem was used by Japanese researcher Kin-itsu Hirata at the Olympic Games in Tokyo 1964 (Hirata, 1966). The presumption of Hirata's hypothesis was that Olympic athletes represent the maximal limit of trainability of their native population, and since they usually carry little body fat, their average physical characteristics (e.g. BMI) could serve as a good tool for the comparison of differences in muscular development. Indeed, the average national values of height and weight in Hirata's study demonstrated remarkable regional differences, when plotted on a graph - and mainly in male European samples that were most representative.

The objection of this study was to measure body height and basic bodily proportions in the youngest age cohorts of the Czech population. These physical parameters would then be compared with other populations and used for the assessment of the national sports potential. In addition to this, the somatic type prevailing in the Czech population will be estimated from the BMI of Olympic team members (Hirata, 1966).

\section{METHODOLOGY}

The measurements took place between summer 2011 and autumn 2012, during various public actions taking place mainly on the territory of Southern Moravia and neighbouring regions. The measured subjects were volunteers, at least 18 years old. The samples were divided according to gender and age. For the purpose of this study, only the youngest age category 18-29 years was selected and included 142 men and 137 women.

The participating individuals underwent a measurement of body height, sitting height and arm span on our measuring device (Figure 1) with the level of accuracy set at $0.1 \mathrm{~cm}$. The initial ideas about the inclusion of other body proportions (mainly body widths) must have been abandoned, with regard to time constraints and difficulties of measuring through clothes. The documented values of sitting height and arm span were divided by body height and used for the calculation of relative indexes of body proportions.

For the estimation of the somatic type prevailing in the Czech population, body height and weight of Czech Olympians was collected from the database on www.sports-reference.com. Subsequently, average BMI of Czech/Czechoslovak teams at the Summer Olympic Games 1964, 1972, 1988, 2000, 2008 and 2012 was calculated. Average values of body height and BMI were then plotted on a graph, together with the same average values of other European teams.

The measured values were processed via a statistical program STATISTICA, version 9.0.

\section{RESULTS}

The results of the anthropometric measurements are presented in Table 2.

\section{Body height}

Although the sample was relatively small, the height of young Czech men $(181.0 \pm 6.2 \mathrm{~cm})$ and women $(168.8 \pm 6.7 \mathrm{~cm})$ fits favourably into the long-term secular trend of body height in the Czech republic (Figure 1). The height of women is higher than we would expect from the current ratio between male and female height (1.072, in contrast with 1.078 in Table 1), and will probably slightly decrease to ca. $168 \mathrm{~cm}$ during the further course of this project. Here it should be noted that during the 6th anthropological survey in 2001, the average height of Czech youngsters with university-educated mothers was $181.1 \mathrm{~cm}$ and $168.1 \mathrm{~cm}$, 
respectively (J. Vignerová - personal communication). The height of privileged societal classes can indicate the future growth potential of the population.

Table 2. Body height and proportions in young Czech men and women.

\begin{tabular}{lcccccc} 
Category & $\mathbf{n}$ & $\begin{array}{c}\text { Body height } \\
(\mathbf{c m})\end{array}$ & $\begin{array}{c}\text { Sitting } \\
\text { height }(\mathbf{c m})\end{array}$ & $\begin{array}{c}\text { Index of } \\
\text { sitting height } \\
(\%)\end{array}$ & $\begin{array}{c}\text { Arm span } \\
(\mathbf{c m})\end{array}$ & $\begin{array}{c}\text { Index of arm } \\
\text { span }(\%)\end{array}$ \\
\hline MEN 18-29 $(\mathrm{y})$ & 142 & $181.0 \pm 6.2$ & $95.2 \pm 3.5$ & $52.63 \pm 1.34$ & $183.6 \pm 7.0$ & $101.46 \pm 2.31$ \\
min-max & & $166.5-195.3$ & $85.5-107.0$ & $46.54-56.61$ & $161.0-203.6$ & $95.44-107.41$ \\
WOMEN 18-29 (y) & 137 & $168.8 \pm 6.7$ & $90.1 \pm 3.4$ & $53.38 \pm 1.47$ & $167.5 \pm 7.8$ & $99.23 \pm 2.40$ \\
min-max & & $146.3-185.0$ & $81.0-98.8$ & $49.42-58.63$ & $142.9-194.5$ & $91.16-105.14$ \\
\hline
\end{tabular}

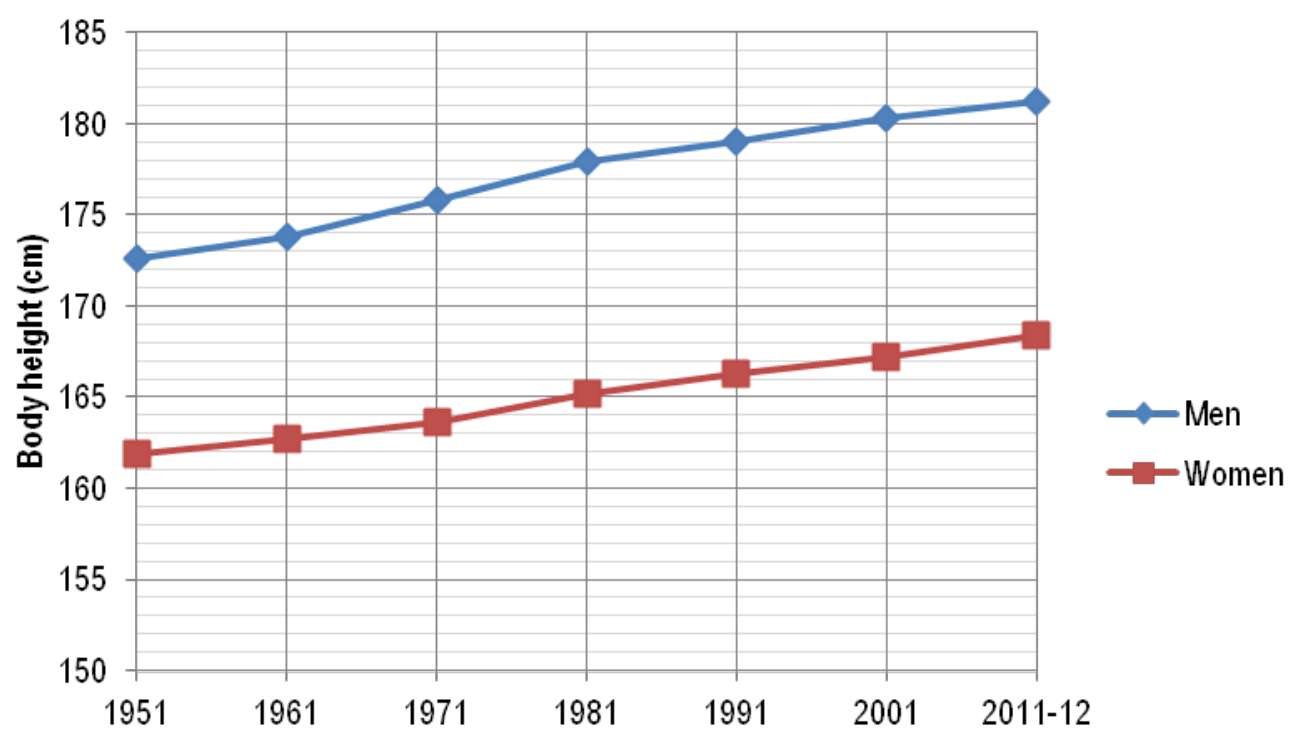

Figure 1. Secular trend of body height in young Czech men and women. Values from 1951-2001 come from regular anthropometric surveys. Values from 2011-12 come from this study.

In any case, even the average values from the 6th anthropological survey (2001) would place the current Czech generation among the tallest nations in the world (Table 3). The height of young Czech men in this study $(181.0 \mathrm{~cm})$ would be the 7 th highest documented in the last decade, and the 4 th highest, if potentially non-representative samples from Montenegro, Germany and Sweden were excluded. 
Table 3. The tallest nations/ethnic groups in the world (according to height of young males).

\begin{tabular}{|c|c|c|c|c|}
\hline Country/region & Age & Date & Height & Source \\
\hline Dalmatia \& Herzegovina & 17 & $2001-03$ & 184.6 & Pineau et al., 2005 \\
\hline Netherlands & 21 & 2010 & 183.8 & 5th Dutch nation-wide growth study \\
\hline Montenegro 1 & $\sim 21$ & 2011 & 183.2 & S. Popovic - pers. communication \\
\hline Germany $^{2}$ & $26-40$ & 2007-09 & 181.5 & Seidl et al. (SizeGERMANY 2007-09) - pers. communication \\
\hline Sweden ${ }^{3}$ & 19 & 1986 & 181.4 & Lindgren et al., 1995 \\
\hline Lithuania & 18 & 2001 & 181.3 & Tutkuviene, 2005 \\
\hline Czech republic & $18-29$ & $2011-12$ & 181.0 & (preliminary results of a survey made by the authors) \\
\hline Serbia & $20-29$ & 2006 & 180.9 & J. Grozdanov - pers. communication \\
\hline Denmark & conscripts & 2006 & 180.6 & Denmark Statistical Yearbook 2007 \\
\hline Iceland & 20 & $1983-87$ & 180.6 & Dagbjartsson et al., 2000 \\
\hline Croatia & 18 & 2006-08 & 180.5 & Juresa et al., 2012 \\
\hline Estonia & 18 & & 180.3 & Grünberg et al.,1998 \\
\hline Belgium & 18 & 2005 & 179.5 & DINBelg 2005. http://www.dinbelg.be/18ansgarcons.htm \\
\hline Norway & $18-19$ & 2010 & 179.5 & Statistics Norway \\
\hline Slovakia & 18 & 2001 & 179.4 & Ševčíková et al., 2004 \\
\hline Somali (Jijiga. Eth.) & young men & & 179.3 & De Lucia et al., 2002 \\
\hline US whites & $20-39$ & 2003-06 & 178.9 & McDowell et al., 2008 \\
\hline Australia (whites) & $25-30$ & $1999-2000$ & 178.7 & S. Tanamas - pers. communication \\
\hline Poland & 18 & 2007-09 & 178.5 & Kułaga et al., 2010 \\
\hline Finland & $25-34$ & 2007 & 178.4 & Peltonen et al., (FINRISK 2007) \\
\hline Scotland & $25-34$ & 2008 & 178.2 & http://www.scotland.gov.uk/Publications/2009/09/28102003/79 \\
\hline Switzerland & $18-22$ & 2009 & 178.2 & Staub et al., 2011 \\
\hline Austria & $18-19$ & $2001-05$ & 178.1 & E. Schober - pers. communication \\
\hline Greece & $18-26$ & $2006-07$ & 178.1 & Papadimitriou et al. 2008 \\
\hline Slovenia & $25-29$ & $2002-03$ & 178.1 & http://www.cindi-slovenija.net \\
\hline Sudan & young men & $1999-2000$ & 178.1 & Rebacz, 2006 \\
\hline US blacks & $20-39$ & $2003-06$ & 178.0 & McDowell et al., 2008 \\
\hline Francie & $18-29$ & 2006 & 177.8 & French nutrition and health survey: the "ENNS Survey. 2006" \\
\hline Latvia & $18-25$ & $1996-98$ & 177.6 & Gerhards, 2005 \\
\hline England & $25-34$ & 2008 & 177.6 & Health Survey for England, 2008 \\
\hline
\end{tabular}

\section{Sitting height}

The average sitting height in men $(52.63 \pm 1.34 \%)$ and women $(53.38 \pm 1.47 \%)$ would indicate a short-legged body type in the European context (Figure 2). However, these results differ from those previously published (Tables $4 \mathrm{a}$ and $4 \mathrm{~b}$ ) that indicate a rather long-legged body type with values ranging between 51.69$52.13 \%$. Considering that the measurement of sitting height is easily prone to error (due to a lack of compliance with the regard to the upright position of the trunk) and often occurs in improvised conditions, it is possible that these previous results are not accurate. The data obtained by our research are closer to those that we encounter in neighbouring countries (Figure 2). Actually, during the course of our project, we put a strong emphasis on the high accuracy of our measurements, and we couldn't find any malfunction on the constructed device that could skew the results. Furthermore, the high values of relative sitting height appeared even in older age categories of men and women (see Tables 4a and 4b). 
Table 4a. Relative sitting height in Czech men.

\begin{tabular}{lcccccc}
$\begin{array}{l}\text { Index of } \\
\text { sitting } \\
\text { height } \\
(\%)\end{array}$ & $\mathbf{n}$ & Age & $\begin{array}{c}\text { Height } \\
\text { (cm) }\end{array}$ & $\begin{array}{c}\text { Sitting } \\
\text { height } \\
\text { (cm) }\end{array}$ & $\begin{array}{c}\text { Leg length } \\
\text { (cm) }\end{array}$ & Source \\
\hline 51.69 & 83 & $\# 20.8$ & 178.0 & 92.0 & 86.0 & Pavlík, 1971 \\
51.91 & - & $18.00-18.99$ & 175.3 & 91.0 & 84.3 & Seliger \& Bartunněk, 1977 \\
52.13 & 72 & $18.00-18.99$ & 178.9 & 93.3 & 85.7 & Jirák et al., 2003 \\
51.52 & 3110 & $58.9 \pm 7.0$ & 174.9 & 90.1 & 84.8 & Webb et al., 2008 \\
52.00 & 157 & $19-64$ & 179.6 & 93.4 & 86.2 & Kovařik, 2011 \\
52.63 & 142 & $18-29$ & 181.0 & 95.2 & 85.8 & this study \\
52.51 & 254 & $30-39$ & 180.5 & 94.7 & 85.8 & this study \\
\hline \multicolumn{7}{c}{ Note: Leg length was computed from body height minus sitting height. \# Without Standard deviations. }
\end{tabular}

Table 4b. Relative sitting height in Czech women.

\begin{tabular}{lcccccc}
$\begin{array}{l}\text { Index of sitting } \\
\text { height (\%) }\end{array}$ & $\mathbf{n}$ & Age & Height $(\mathbf{c m})$ & $\begin{array}{c}\text { Sitting } \\
\text { height }(\mathbf{c m})\end{array}$ & $\begin{array}{c}\text { Leg length } \\
(\mathbf{c m})\end{array}$ & Source \\
\hline 53.29 & -- & $18.00-18.99$ & 164.0 & 87.4 & 76.6 & Seliger \& Bartůněk, 1977 \\
52.59 & 53 & $18.00-18.99$ & 167.7 & 88.2 & 79.5 & Jirák et al., 2003 \\
52.44 & 3634 & $58.0 \pm 6.9$ & 161.9 & 84.9 & 77.0 & Webb et al., 2008 \\
52.80 & 161 & $18-62$ & 166.3 & 87.8 & 78.5 & Kovařik, 2011 \\
53.38 & 137 & $18-29$ & 168.8 & 90.1 & 78.7 & This study \\
53.32 & 281 & $30-39$ & 168.2 & 89.7 & 78.5 & This study \\
\hline
\end{tabular}

Note: Leg length was computed from body height minus sitting height.

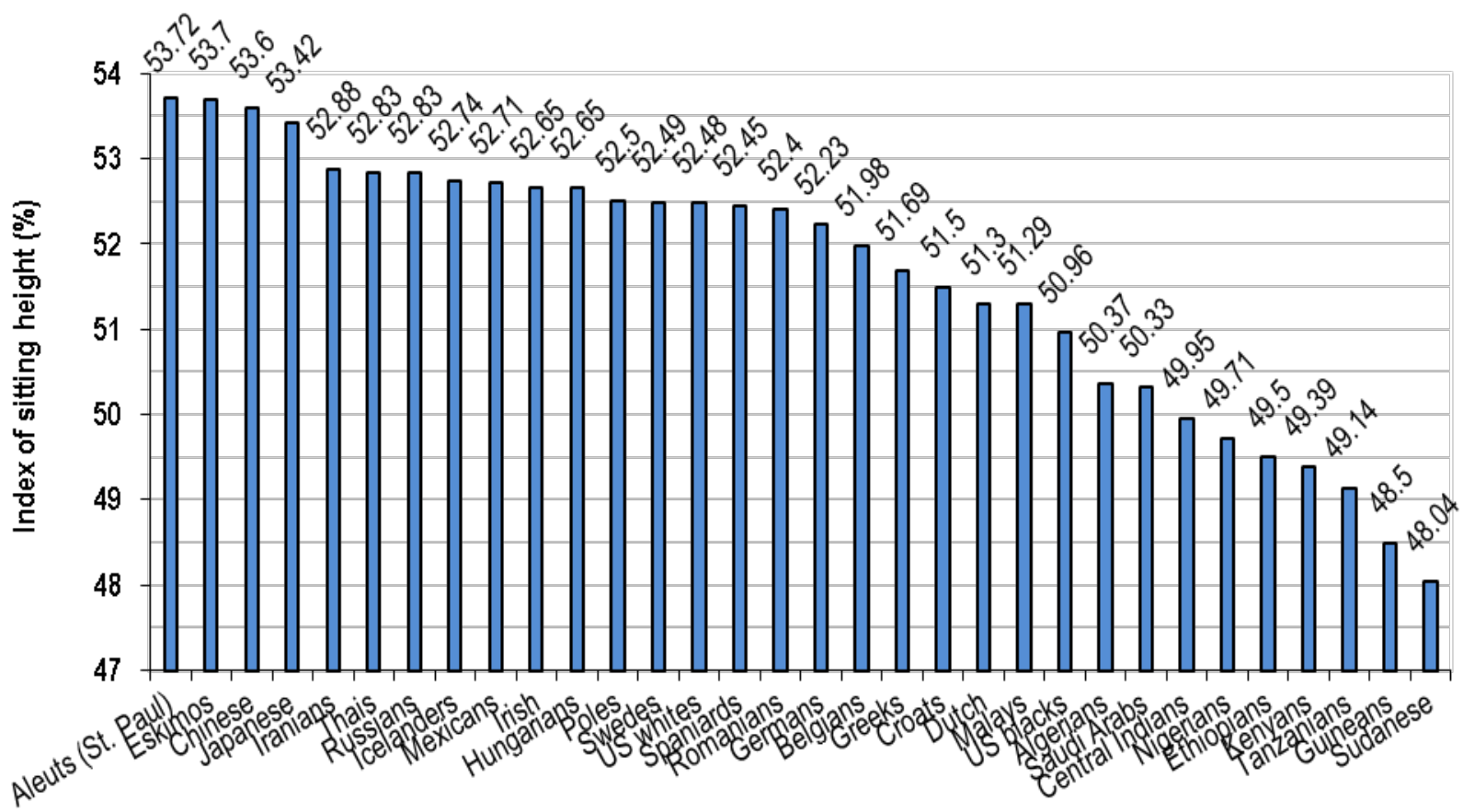

Figure 2. Relative sitting height in some selected world populations. 
Interestingly, there was a significant negative correlation between body height and the index of sitting height, both in men and women (Figure 3). This is in accordance with some previous studies (Fredriks et al., 2005; Küchmeister et al., 2009). In other words, persons with above-average height have relatively longer legs than individuals with below-average height. Women have relatively shorter legs than men, which is a usual anthropometric trend (Norton \& Olds, 1996). In general, the range of sitting height indices was between $\sim 50-54 \%$ in men and $\sim 51-56 \%$ in women. Only rarely we observed values in the usual range of long-legged tropical nations; some eccentric numbers (below $49 \%$ in men) may rather be due to occasional errors during the recording of the data (Figure 3).

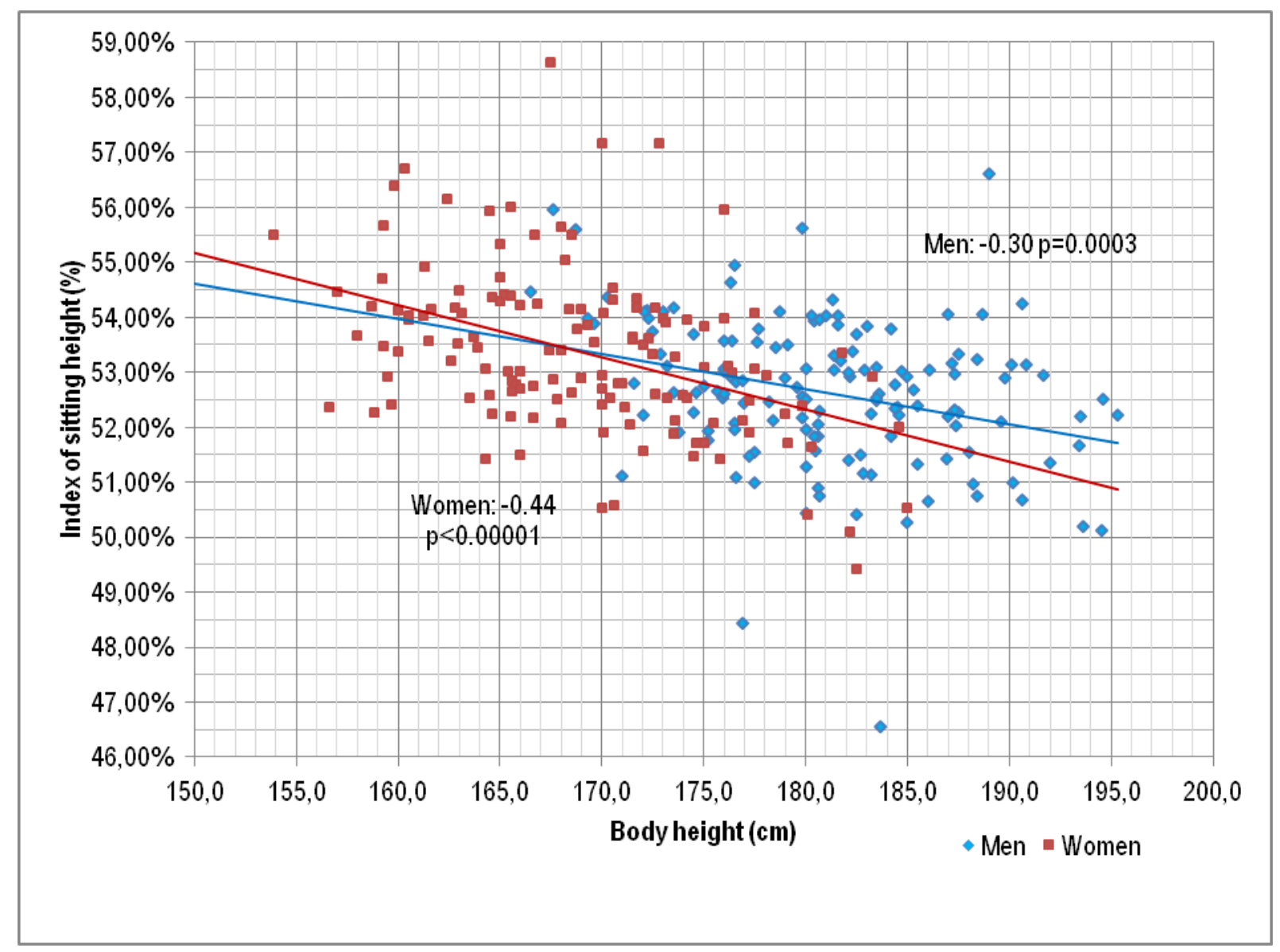

Figure 3. Correlation between body height and the index of sitting height.

\section{Arm span}

The average indexes of arm span ( $101.46 \pm 2.31 \%$ in men, $99.23 \pm 2.40 \%$ in women) are perfectly in line with the indexes of sitting height and indicate a short-armed body (Table 5). However, the measurement of the arm span doesn't take the width of the trunk into consideration and its information value is thus limited. Our results agree very well with previous studies (Table 6), which is not so surprising, with regard to the much lesser chance of measurement errors. 
Quite expectably, there was a very strong positive relationship between body height and arm span, both in men $(r=0.81, p<0.000001)$ and women $(r=0.85, p<0.000001)$. On the other hand, there was no relationship between body height and relative arm span, although it approached statistical significance in men (men: $r=-$ $0.16, p=0.055$; women: $r=-0.02, p=0.83$ ). Interestingly, in men in the age group 30-39 years, the relationship was statistically significant $(r=-0.20 ; p=0.03)$. This result is surprising and indicates than in men, there may be a trend towards a lower arm span and possibly a leaner body shape with increasing height.

Table 5. Some examples of indices of arm span from recent literature (men).

\begin{tabular}{lcccc} 
& $\begin{array}{c}\text { Index of arm } \\
\text { span }(\%)\end{array}$ & $\begin{array}{c}\text { Body height } \\
(\mathbf{c m})\end{array}$ & $\begin{array}{c}\text { Arm span } \\
(\mathbf{c m})\end{array}$ & Source \\
\hline Montenegro & 101.4 & 183.2 & 185.7 & S. Popović - pers. communication \\
Denmark & 102.0 & 180.7 & 184.3 & Hertel et al., 1995 \\
Philippines & 100.5 & 167.9 & 167.0 & Del Prado-Lu, 2007 \\
Ghana & 107 & -- & -- & Tayie et al., 2003 \\
India & 105.9 & 162.9 & 172.6 & Chhabra, 2008 \\
Iran & 104.5 & 171.6 & 179.3 & Golshan et al., 2003 \\
Nigeria & 103.3 & 167.2 & 172.7 & Ter Goon et al., 2011 \\
Ethiopians (Oromo) & 104.6 & 168.2 & 176 & De Lucia et al., 2002 \\
Turkey & 101.4 & 174.6 & 177.1 & Mazicioglu et al., 2009 \\
Vietnam & 102.5 & 162.8 & 166.9 & Tam et al., 1999 \\
\hline
\end{tabular}

Table 6. Indices of arm span in Czech men and women.

\begin{tabular}{lccccc} 
Index of arm span (\%) & $\mathbf{n}$ & Age & Body height $(\mathbf{c m})$ & Arm span $(\mathbf{c m})$ & Source \\
\hline Men & & & & & \\
101.01 & 83 & $\# 20.8$ & 178.0 & 179.8 & Pavlik, 1971 \\
101.00 & 157 & $18-64$ & 179.6 & 181.4 & Kovařik, 2011 \\
101.46 & 142 & $18-29$ & 181.0 & 183.6 & this study \\
101.53 & 254 & $30-39$ & 180.5 & 183.2 & this study \\
Women & & & & & \\
99.16 & 161 & $18-62$ & 166.3 & 164.9 & Kovařik, 2011 \\
99.23 & 137 & $18-29$ & 168.8 & 167.5 & This study \\
99.16 & 281 & $30-39$ & 168.2 & 166.8 & This study \\
\hline
\end{tabular}

\#Without Standard deviations.

\section{Somatic type}

In accordance with the early Hirata's findings, the comparison of physical characteristics in male European Olympic team members (across 5 Summer Olympic games since 1964) produced surprisingly illustrative results (Figures $4 \mathrm{a}$ and $4 \mathrm{~b}$ ). The BMI of male Olympians shows clear geographical tendencies, with East European teams being consistently heavier than West European teams. In the Czech Olympians, BMI is regularly around $24.5 \mathrm{~kg} / \mathrm{m}^{2}$, which is an above-average value in the European context. For example, in Atlanta 1996 it was $24.45 \mathrm{~kg} / \mathrm{m}^{2}$, in Sydney $200024.75 \mathrm{~kg} / \mathrm{m}^{2}$, in Peking $200824.63 \mathrm{~kg} / \mathrm{m}^{2}$, in London 2012 $24.37 \mathrm{~kg} / \mathrm{m}^{2}$. Even the average BMI in four Czech international medal winners in athletics since 1993 has been $24.36 \mathrm{~kg} / \mathrm{m}^{2}$. In Czech women, BMl averages are typically around $21.5 \mathrm{~kg} / \mathrm{m}^{2}$ (e.g. in London 2012 it was $21.61 \mathrm{~kg} / \mathrm{m}^{2}$, in international medal winners in athletics since $1993-21.63 \mathrm{~kg} / \mathrm{m}^{2}$ ). 
Although the average height of male Olympians is always ca. $+5-6 \mathrm{~cm}$ higher than in the general population (which is due to the requirements of many Olympic sports), the correlation between the "Olympic height" and "national height" is statistically very significant. For example, in Peking 2008, it reached $r=0.73$ $(p<0.000005)$ in 30 European countries. The plot of height and BMl thus allows a mutual comparison of basic physical differences among all European nations, which can have fundamental implications (Figures $4 a$ and $4 b)$.

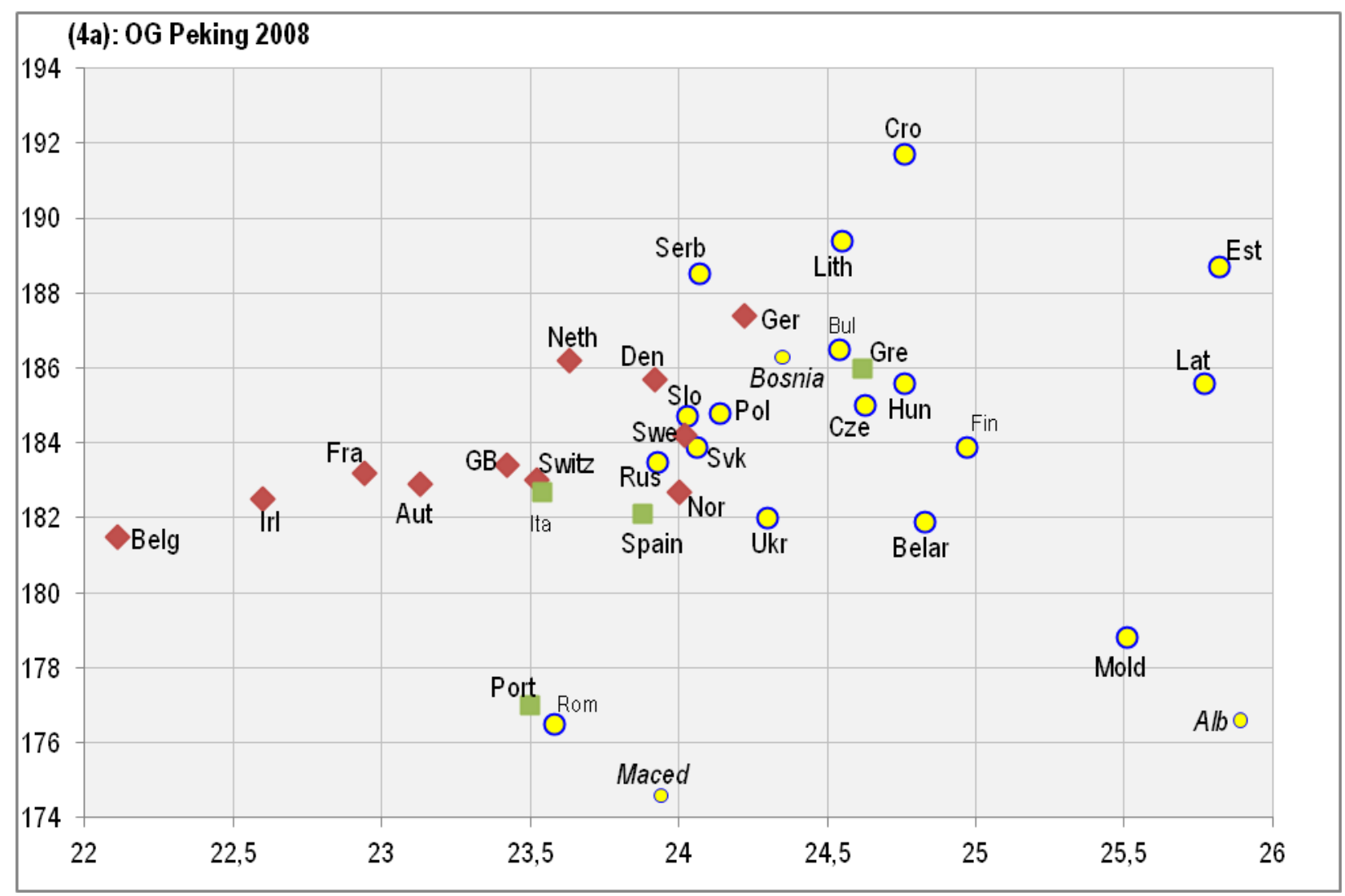

Figure 4a. Height and BMI values of male European Olympians in Peking 2008 (32 countries). The samples included only Olympians having at least one parent of local origin or naturalized Olympians coming from a neighbouring country. The average of all European countries was $184.1 \mathrm{~cm}, 24.10 \mathrm{~kg} / \mathrm{m}^{2}$. The graph also includes samples of Albania, Bosnia \& Herzegovina and Macedonia computed from OG 1996-2008 (small dots). 


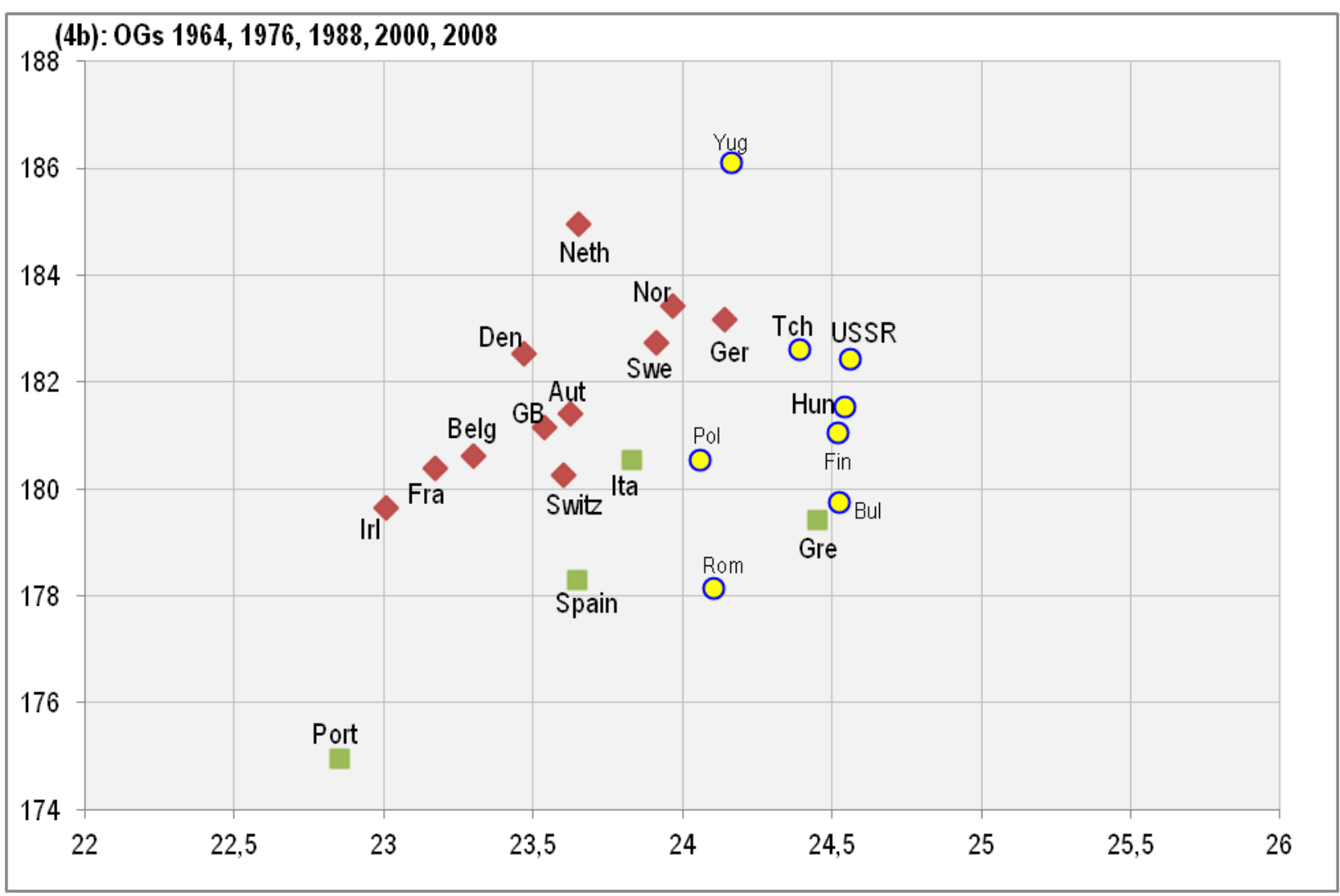

Figure 4b. Summary averages of height and BMI in 23 European teams computed from values in Tokyo 1964, Montreal 1972, Seoul 1988, Sydney 2000 and Peking 2008. The European average in this case would be $181.1 \mathrm{~cm}, 23.87 \mathrm{~kg} / \mathrm{m}^{2}$. In 3 teams (USSR, Czechoslovakia, Yugoslavia) we used an unweighted average of their (European) successor states in Sydney and Peking. For Germany, only data for West Germany from Tokyo were available. In Montreal and Seoul, we computed an average of West and East

\section{Germany.}

\section{DISCUSSION}

The results of this study indicate that the body type of Czech men and women is very tall, with short limbs and above-average level of muscular robuscity. The evaluation of the Czech somatotype is based only on the BMI of Olympic team members, and there is rather little evidence to support the validity of these BMI values, except their historical and geographical consistency. Nevertheless, the correlation between BMI differences in 7 ethnic groups from the review of Deurenberg et al. (1999) and the same 7 ethnic samples from Peking 2008 reaches $r=0.96$ ( $p=0.00076$ ), which doesn't allow many other explanations but a very strong confirmation of Hirata's thesis (Figure 5). The BMI of Olympic team members thus very probably really reflect the prevailing body type of the general population, although it is undoubtedly influenced by population size. In small nations with limited talent pools, this physical type is exaggerated, while populous nations have rather moderate values, because they have enough talents to cover virtually all Olympic sports (see the position of Russia on Figure 4a, contrasting with extreme BMI values of Estonians and Latvians). 
Knowing the physical characteristics of the Czech population, we can potentially plan talent programs much more rationally. It is quite clear that they should be aimed at sports, where exceptional height together with strength (of a more dynamic nature) is an advantage. Simple calculations can show us that at the $190 \mathrm{~cm}$ mark, the potential of the Czech male population is about 2.7-times higher per capita than that of France, which means that in absolute numbers, the advantage of France is only ca. twice higher, despite a 6 -fold difference in population. At $200 \mathrm{~cm}$, the size of the talent pools in the Czech republic and France should not be much different, because the number of Czech men with this height is ca. 5.7-times higher per capita.

Anecdotal evidence indeed suggests that Czech sportsmen particularly excel in individual activities like rowing, javelin throw and the decathlon, sports with above-average BMI requirements $\left(25-27 \mathrm{~kg} / \mathrm{m}^{2}\right)$, where average participants are ca. $190 \mathrm{~cm}$ tall. In athletics, we could expect that Czechs should do very well even in the high jump, triple jump and discus throw. In the latter two events, this is not the case in the recent years, which indicates that the Czech potential has not been fully realized here. Shot put and hammer throw would be a good option as well, although here the average Czech athlete would be less talented when compared with more robust East Europeans. In track, the $400 \mathrm{~m}$ distance, followed by the $110 \mathrm{~m}$, would fit Czech runners best, due to above-average height requirements $(\sim 186 \mathrm{~cm})$ and mesomorphic somatotype (BMl $\left.\sim 23 \mathrm{~kg} / \mathrm{m}^{2}\right)$. There are also other Olympic sports, where we could expect notable international success of Czech men and women: Swimming, fencing, heavyweight classes of martial sports (especially taekwondo and boxing), canoeing, bobsleigh. In extreme strength sports, the chance of Czechs would certainly be better in powerlifting than in weightlifting, where height is less important.

In contrast, the Czech body type seems to be too robust for such popular sports like road cycling and triathlon (BMI $\left.\sim 21 \mathrm{~kg} / \mathrm{m}^{2}\right)$. It can be assumed that here the number of excellent Czech racers will never be too large. The high BMI and extreme height also show that the funding of endurance running, diving, trampoline and gymnastics wouldn't be rational, because elite competitors must be very lean and/or very small. The height/BMl averages of Czech Olympians progressively move from the area of the plot, where successful participants in these sports are situated. Interestingly, ski jumping and figure skating would also belong to this category, which may seem contradictory, with regard to recent historical success of Czech republic in these winter sports. However, it can be anticipated that in this case, the much smaller international competition at Winter Olympics and necessary infrastructure trump genetics.

In team sports, physical prerequisites make up a much small portion of the final performance than in individual sports. Nevertheless, it is quite clear that the Czech population has a very large talent pool for ice hockey, baseball, waterpolo, volleyball, and especially for basketball and handball.

In summary, the sports potential of the Czech population is exceptionally high on per capita basis, with regard to the fact that the Czech BMI values are not extreme and most sports require above-average body size. In some sports, international success emerges quite naturally, as we could expect from the description of the physical characteristics. Good illustrative cases include e.g. rowing, javelin throw, decathlon or recently the $400 \mathrm{~m}$ distance in track. However, there are also some sports, in which we could certainly expect a more visible participation of Czech sportsmen. Especially striking is the lack of success in martial sports, for which the height and BMI of Czech athletes would be practically ideal. These hidden reserves should be addressed by better funding and talent selection in the future. 




Figure 5. Correlations of BMI in 7 Olympic ethnic samples vs. BMI predicted on the basis of fat mass/fatfree mass ratios in 7 identical ethnic groups (see Figure 1). All the Olympic samples were taken from Peking 2008, except the sample of Polynesians (OGs 1996-2008). For the Olympic BMI of „Caucasians", we used the European mean from Peking $2008\left(24.10 \mathrm{~kg} / \mathrm{m}^{2}\right)$.

\section{ACKNOWLEDGMENTS}

The research survey presented above was financed within the project "Creating a research team led by a reintegrated Czech researcher to determine the level of physical activity (inactivity) in chosen age groups of women and men in the Czech republic" (CZ. 1. 07/2. 3. 00/20. 0044).

\section{REFERENCES}

1. 5th Dutch nation-wide growth study (2010). Retrieved from http://www.tno.nl/content.cfm?context=thema\&content=prop_case\&laag1=891\&laag2=902\&laag3= 70\&item_id=1141. 
2. DAGBJARTSSON A, THORNÓRSSON AV, PÁLSSON GI, ARNÓRSSON VH. Hæð og pyngd íslenskra barna og unglinga 6-20 ára. [Height and weight of Icelandic children 6-20 years of age.] Laeknabladid, 2000; 86(7/8):509-514.

3. DE LUCIA E, LEMMA F, TESFAYE F, DEMISSE T, ISMAIL S. The use of armspan measurement to assess the nutritional status of adults in four Ethiopian ethnic groups. Eur J Clin Nutr, 2002; 56(2):91-5

4. DEL PRADO-LUA JL. Anthropometric measurement of Filipino manufacturing workers. International Journal of Industrial Ergonomics, 2007; 37(6): 497-503.

5. Denmark Statistical Yearbook 2007, Retrieved from http://www.dst.dk/pukora/epub/upload/10670/population_2.pdf

6. FREDRIKS AM, VAN BUUREN S, VAN HEEL WJ, DIJKMAN-NEERINCX RH, VERLOOVEVANHORICK SP, WIT JM. Nationwide age references for sitting height, leg length, and sitting height/height ratio, and their diagnostic value for disproportionate growth disorders. Arch Dis Child, 2005; 90(8):807-12.

7. GERHARDS $\mathrm{G}$. Secular variations in the body stature of the inhabitants of Latvia (7th millennium $B C-20$ th C. AD). Acta medica Lituanica, 2005; 12(1): 33-39.

8. GOLSHAN M, AMRA B, HOGHOGHI MA. Is arm span an accurate measure of height to predict pulmonary function parameters? Monaldi Arch Chest Dis, 2003; 59(3):189-92.

9. GRÜNBERG H, ADOJAAN B, THETLOFF M. Kasvamine ja kasvuhäred. Metoodiline juhend laste füüsilise arengu hindamiseks. [Growth and growth disorders. A methodological guide for assessing children's physical development]. Tartu: Tartu Ülikool. 1998.

10. Health Survey for England 2004. Volume 1: The health of minority ethnic groups. Retrieved from http://www.ic.nhs.uk/catalogue/PUB00455/heal-surv-tren-table-eng-2008-tab-v1.xls.

11. HERTEL NT, SCHEIKE T, JUUL A, MAIN KM, HOLM K. Body proportions of Danish children. Curves for sitting height ratio, subischial length and arm span. Ugeskr Laeger, 1995; 157(49):687681.

12. CHHABRA SK. Using arm span to derive height: Impact of three estimates of height on interpretation of spirometry. Annals of Thoracic Medicine, 2008; 3(3): 94-97.

13. JIRÁK Z, ŠIMÍČEK J, BUŽGA M, TOMÁŠKOVÁ H, KŘENKOVÁ M. Trend of fitness and selected anthropological characteristics of young population in the North Moravian region (Czech republic) in past 25 years. Anthropologie, 2003; 41(3):263-276.

14. JIRKOVSKÝ D. Tělesná výška a hmotnost mladých mužů ve věku 1825 let v druhé polovině 20 . století. Vojenské zdravotnické listy, 2003; 72(5):217-220.

15. JURESA V, MUSIL V, TILJAK MK. Growth charts for Croatian school children and secular trends in past twenty years. Coll Antropol, 2012; 36 Suppl 1:47-57.

16. KOBZOVÁ J, VIGNEROVÁ J, BLÁHA P, KREJCOVSKÝ L, RIEDLOVÁ J. The 6th nationwide anthropological survey of children and adolescents in the Czech Republic in 2001. Cent Eur J Public Health. 2004; 12(3):126-30.

17. KOVAŘíK M. Antropometrický výzkum dospělé populace a jeho aplikace $v$ oblasti interiéru a architektury. Dissertation. Brno: VUT Brno, 2011.

18. KUŁAGA Z, LITWIN M, TKACZYK M, PALCZEWSKA I, ZAJACZKOWSKA M, ZWOLIŃSKA D, KRYNICKI T, WASILEWSKA A, MOCZULSKA A, MORAWIEC-KNYSAK A, BARWICKA K, GRAJDA A, GURZKOWSKA B, NAPIERALSKA E, PAN H. Polish 2010 growth references for school-aged children and adolescents. Eur J Pediatr, 2010; 170(5):599-609.

19. LINDGREN G, STRANDELL A, COLE T, HEALY M,TANNER J. Swedish population reference standards for height, weight and body mass index attained at 6 to 16 years (girls) or 19 years (boys). Acta Paediatr, 1995; 84(9):1019-28. 
20. MAZICIOGLU MM, HATIPOGLU N, OZTURK A, GUN I, USTUNBAS HB, KURTOGLU S. Age references for the arm span and stature of Turkish children and adolescents. Ann Hum Biol, 2009; 36(3):308-19

21. MCDOWELL MA, FRYAR CD, OGDEN CL, FLEGAL KM. Anthropometric reference data for children and adults: United States, 2003-2006. National health statistics reports; no 10. Hyattsville, MD: National Center for Health Statistics. 2008.

22. NORTON K, OLDS T. Anthropometrica: a textbook of body measurement for sports and health courses. Sydney, Australia: UNSW Press. 1996.

23. PAPADIMITRIOU A, FYTANIDIS G, DOUROS K, PAPADIMITRIOU DT, NICOLAIDOU $P$, FRETZAYAS A. Greek young men grow taller. Acta Paediatr, 2008; 97(8):1105-7.

24. PAVLÍK J. Somatická charakteristika československých vrcholových gymnastů. Teor. Praxe těl. Vých, 1971; 19(10):586-594.

25. PELTONEN M, HARALD K, MÄNNISTÖ S, SAARIKOSKI L, LUND L, et al. FINRISK 2007. Retrieved from http://www.ktl.fi/attachments/suomi/julkaisut/julkaisusarja_b/2008/2008b35.pdf

26. PINEAU JC, DELAMARCHE P, BOZINOVIC S. Les Alpes Dinariques: un peuple de sujets de grande taille. C R Biol, 2005; 328(9):841-6.

27. REBACZ E. The physique of young males in east Africa from the biosocial point of view. Coll Antropol, 2006; 30(2):259-64.

28. SELIGER V, BARTŮNĚK $Z$. Tělesná zdatnost obyvatelstva ČSSR ve věku 12-55 r. Praha: Universita Karlova. Quoted in: Jirák Z., Šimíček J., Bužga M., Tomášková H., Křenková M. (2003) Trend of fitness and selected anthropological characteristics of young population in the North Moravian region (Czech republic) in past 25 years. Anthropologie, 1977; 41(3):263-276.

29. Statistics Norway, Retrieved from http://www.ssb.no/samfunnsspeilet/utg/201101/08/tab.

30. STAUB K, RÜHLI F, WOITEK U, PFISTER C. The average height of 18- and 19-year-old conscripts ( $N=458,322)$ in Switzerland from 1992 to 2009, and the secular height trend since 1878. Swiss Med Wkly, 2011; 141:w13238.

31. ŠEVČÍKOVÁ Ĺ, NOVÁKOVÁ J, HAMADE J, TATARA M. Rast a vývojové trendy slovenských detí a mládeže za posledných 10 rokov [Growth and development trends in Slovak children and adolescents during the last 10 years]. In: L'ubica Ághová (Ed.). Životné podmienky a zdravie [Living conditions and health]. Bratislava: Úrad verejného zdravotníctva SR. 2004.

32. TAM TTT, GROSS R, LUKITO W, RUMAWAS JSP. Chronic energy deficiency and relative abdominal overfatness coexist in free-living elderly individuals in Ho Chi Minh City, Vietnam. Asia Pacific Clin Nutr, 1999; 8(2):129-135.

33. TAYIE F, AGYEKUM S, OWUSU AHENKORA M, BUSOLO D, ADJETEY-SORSEY E. Armspan and halfspan as alternatives for height in adults: a sample from Ghana. African Journal of Food Agriculture Nutrition and Development, 2003; 3(2).

34. TER GOON D, TORIOLA AL, MUSA DI, AKUSU S. The relationship between arm span and stature in Nigerian adults. Kinesiology, 2011; 43(1):38-43.

35. TUTKUVIENE J. Sex and gender differences in secular trend of body size and frame indices of Lithuanians. Anthropol Anz, 2005; 63(1):29-44.

36. VIGNEROVÁ J, BRABEC M, BLÁHA P. Two centuries of growth among Czech children and youth. Econ Hum Biol, 2006; 4(2):237-52.

37. VIGNEROVÁ J, RIEDLOVÁ J, BLÁHA P, KOBZOVÁ J, KREJČOVSKÝ L, BRABEC M, HRUŠKOVÁ M. Celostátní antropologický výzkum dětí a mládeže 2001. Česká republika. Souhrnné výsledky. Praha: PřF UK, SZÚ. 2006.

38. WEBB E, KUH D, PEASEY A, PAJAK A, MALYUTINA S, KUBINOVA R, TOPOR-MADRY R, DENISOVA D, CAPKOVA N, MARMOT M, BOBAK M. Childhood socioeconomic circumstances 
and adult height and leg length in central and eastern Europe. J Epidemiol Community Health, 2008; 62(4):351-7. 